\title{
A DEVICE FOR SIMULATING SOLAR ELECTROMAGNETIC RADIATION MICROWAVE BURSTS
}

\author{
S.N. Darovskikh', darovskih.s@mail.ru, \\ Yu.S. Shishkova², shishkova_yulia@mail.ru, \\ N.V.Vdovina1, nadzh@yandex.ru, \\ N.N. Gudaev', gudaevnn@susu.ac.ru, \\ V.N. Bagaev', bagaevvn@susu.ac.ru, \\ A.R.Komogorova1, komogorovaar@susu.ru, \\ D.V. Kochkina', englmnk@gmail.com, \\ O.J.A. Abdalgabar \\ ${ }^{1}$ South Ural State University, Chelyabinsk, Russian Federation, \\ ${ }^{2}$ South Ural Medical University, Chelyabinsk, Russian Federation
}

\begin{abstract}
There has been grounded the relevance of carrying out the research on the estimation of the modifying role of the Sun microwave radiation splashes on biorhythms of organisms. It has been noted that the necessary condition of such research realization is impossible without the construction of a device for microwave bursts simulating. There are provided the main characteristics that determine the physical basis for such a device construction, as well as its functional capabilities. The constructed device for simulating solar electromagnetic radiation microwave bursts in the frequency range of about $4 \mathrm{GHz}$ has no analogues in the world. It allows us to obtain new knowledge about the interaction of organisms with electromagnetic radiation of natural and technogenic origin, its influence on various high-frequency biorhythms of organisms and microorganisms in particular.

Keywords: microwave bursts, biorhythms, microwave radiation.
\end{abstract}

\section{Introduction}

One of the topical issues concerning carrying out the research to assess the effect of solar microwave radiation splashes on high-frequency (from a second to half an hour) and on mid-frequency (from 20 hours to 3 days) biorhythms of organisms is the lack of devices for their adequate modeling. The importance of such devices construction is due to a number of factors. The first one has purely theoretical basis and is connected with the desire to understand the role of such an important for organisms exogenous factor as the Sun in the process of high-frequency biorhythms formation and genetic fixation in them. Investigation of this role is hampered by the low density of solar microwave radiation real outbursts intensity (about $10^{-16} \mu \mathrm{W} / \mathrm{cm}^{-2} \mathrm{~Hz}^{-1}$ at the surface of the Earth) [1].

The second factor has a pronounced practical orientation and it underlines the fact that the controlling role on the biota of the natural electromagnetic factor in the form of the solar microwave radiation reaching the Earth's surface (wavelength from $8 \mathrm{~mm}$ to $15 \mathrm{~m}$ ) has noticeably weakened due to electromagnetic pollution of the environment by modern infocommunication systems (mobile communication systems, satellite navigation systems, etc.) [2]. At present, the radiation intensity levels of these systems often exceed $10-100 \mu \mathrm{W} / \mathrm{cm}^{2}$ [3]. In many countries of the world, these values are considered to be minimally safe for humans. However, if you pay attention to some recent trends related to the rise in the number of cancer diseases, increased resistance of pathogenic and opportunistic microorganisms to antibiotics, etc., it becomes evident that the abovementioned sources of man-made pollution are potentially dangerous for organisms and humans in particular.

In this regard the paradox of the current situation is that at present and in the future mankind will not be able to abandon wireless infocommunication systems because they have dramatically improved the communication quality of life for large groups of the world's population. As for the abovementioned potential dangers associated with infocommunication systems massive use, then, according to many representatives of the human community, they are clearly exaggerated. However, real life, as it has been noted above, indicates the existence of an inverse pattern. Some scientists forecast that the failure to take effective measures to counter electromagnetic pollution of the environment can lead to the increased 
number of inflammatory diseases with a lethal outcome due to the lack of necessary antibiotics in the near future (10-15 years) [4].

In this situation the task of finding ways to weaken the changes in the electromagnetic properties of the environment for organisms is becoming fundamentally important. At the same time, the initial stage of this problem solution must undoubtedly be connected with the study of the possibility of using a simulated natural electromagnetic factor to correct the violations of evolutionarily generated high-frequency biorhythms of pathogenic and opportunistic microorganisms. These biorhythms define the necessary operational rhythmic sequence of physiological, metabolic and biochemical processes in them and the optimal ratio of their parameters at each moment of time [5]. Since microorganisms are the most sensitive indicators of changes in the properties of the environment, the changes in their biorhythms will be the first signal. In this regard, the study of these changes peculiarities at the cellular level will make it possible to develop proposals for their correction aimed at reducing the resistance of microorganisms. The results of these studies and the main recommendations formulated on their basis can be used to synchronize biorhythms at the organism level as well.

Thus, the development of a device for simulating solar electromagnetic radiation microwave bursts is a necessary condition for obtaining new knowledge about the modifying effect of this radiation on the biorhythms of organisms.

\section{The basic relations determining the possibility of solar microwave bursts simulating}

\section{and the construction features of the device for their generation}

Up to date information concerning solar microwave bursts of the centimeter wavelength range, which is most consistent with organisms, comes down only to three types of pulsations (bursts) of electromagnetic radiation intensity [6]:

- type A - rapid rise and decline, lifetime (1-5) min, radiation is polarized;

- type B - rapid rise and slow decline, lifetime - from several minutes to several hours, radiation polarization is not known;

- type C - gradual rise and decline, lifetime - from several tens of minutes to several hours, radiation polarization is not known.

All types of microwave bursts can exist separately or overlap. The most powerful pulsations of electromagnetic radiation intensity are of type A or type B. They reflect explosive processes occurring in the Sun chromosphere.

These bursts are characterized by a pronounced change in the width of the electromagnetic radiation spectrum and its intensity. The initial period of the burst rise is associated with the broad radiation spectrum. Then there takes place its rise accompanied by its narrowing. The intensity of the radiation increases with the rise of the burst. A reverse process, i.e. the return to the initial state, happens after reaching the rise peak. The abovementioned bursts can be either single or multiple with regular and irregular frequency.

The possibility of implementation of the above-described radiation properties in the simulating of solar microwave bursts by means of a signal generator with a parallel or series contour is based on the known coupling of the width of the vibration spectrum $\Delta f$ with the central (resonant) frequency $f_{0}$ and the quality factor $Q$, determined by the formula [7]

$\Delta f=f_{0} / Q$.

It follows from this that the spectral with $\Delta f$ control can be achieved by a corresponding change in the quality factor $Q$. $Q$, in its turn, is related to the carrier frequency $f_{0}$, the energy stored in the oscillating system $W$, and the power dissipation Pd by the relation [7]

$$
Q=2 \pi f_{0} W / P_{d} \text {. }
$$

It follows from this that the change in $Q$ of the oscillatory system is directly related to the change in the energy stored in the contour.

Since the value of this energy is determined by the relation

$W=q_{\max }^{2} / 2 C=L I_{\max }^{2} / 2$,

where $q_{\max }$ is the maximum value of the charge accumulated on the plates of capacitor $C$, which is the part of the contour; $I_{\max }$ - the maximum current flowing through the inductance $L$ of the contour, it follows from this that the control of the energy stored in the contour, and therefore the change in its quality factor $Q$, can be carried out by the voltage applied to the contour. In this case, the value of the out- 


\section{Краткие сообщения}

put power of the generator system, which determines the intensity of electromagnetic radiation, will be proportional to the quality factor $Q$. The magnitude of the power dissipation $P_{d}$ when controlling the $Q$-factor of the contour can be assumed to be equal to a constant value.

Proceeding from the properties of microwave bursts considered above and the physical capabilities of their simulating, there has been constructed the devices for their polarized (Fig. 1a) and unpolarized radiation (Fig. 1b) in the frequency range of about $4 \mathrm{GHz}$ with microprocessor controlled modes of operation based on the ARM processor STV32F103. They represent a deep structural upgrade of another device for simulating the solar microwave radiation AIMT-1 (apparatus for information microwave therapy) [8].

Functionally, the devices comprise of the following structural elements: a modulator, a highfrequency generator with the power generation and control unit, and an antenna (Fig. 2).

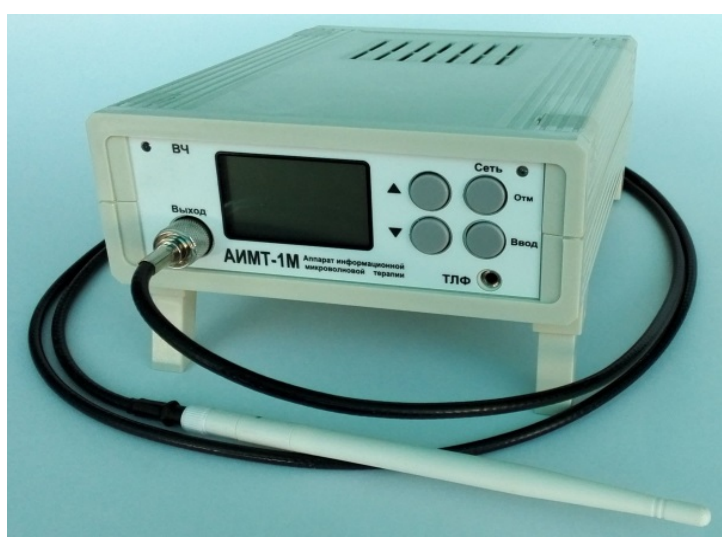

a)

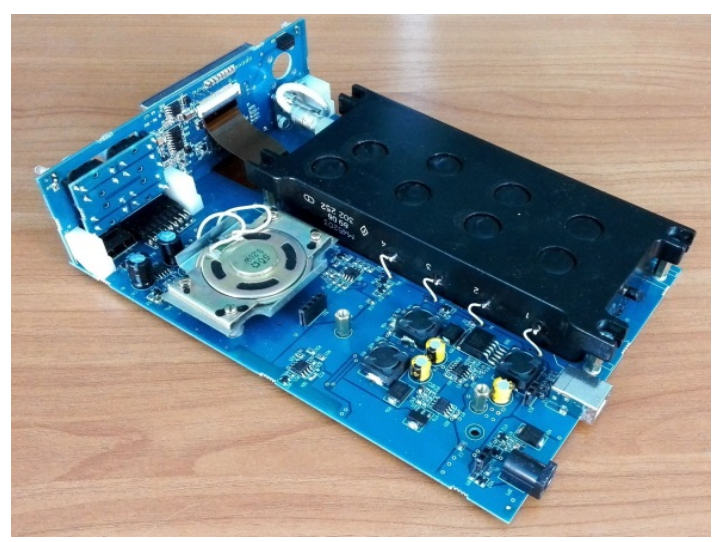

b)

Fig. 1. A device for simulating polarized solar electromagnetic radiation microwave bursts: a - appearance; $b$ - structural features

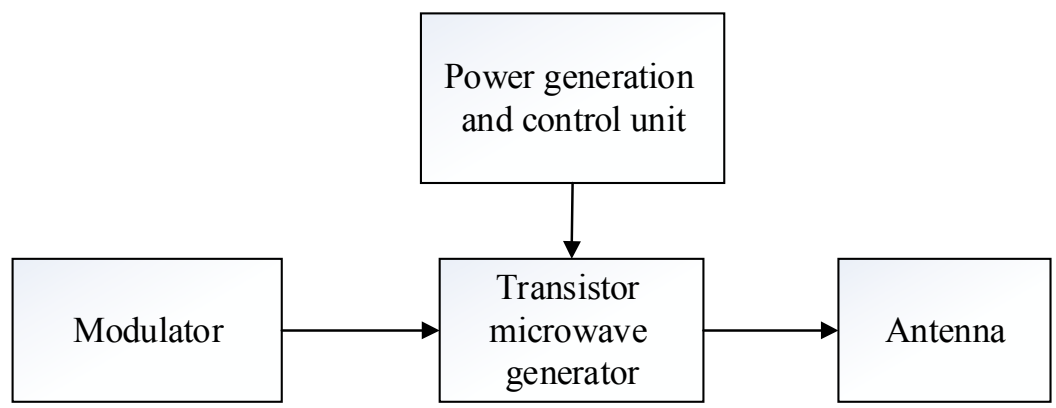

Fig. 2. Construction pattern of the device for solar bursts simulating

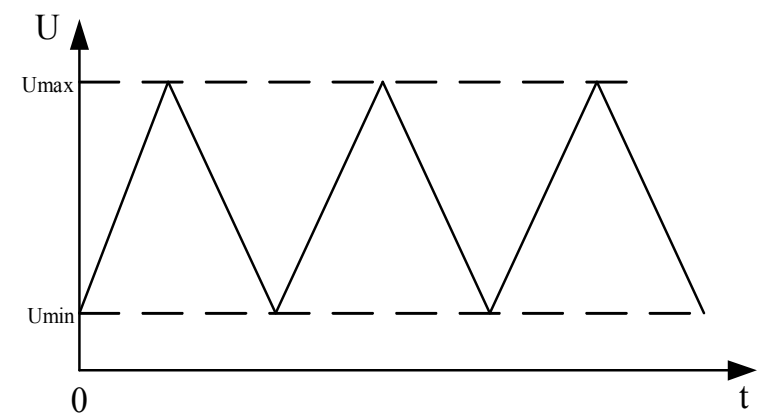

a)

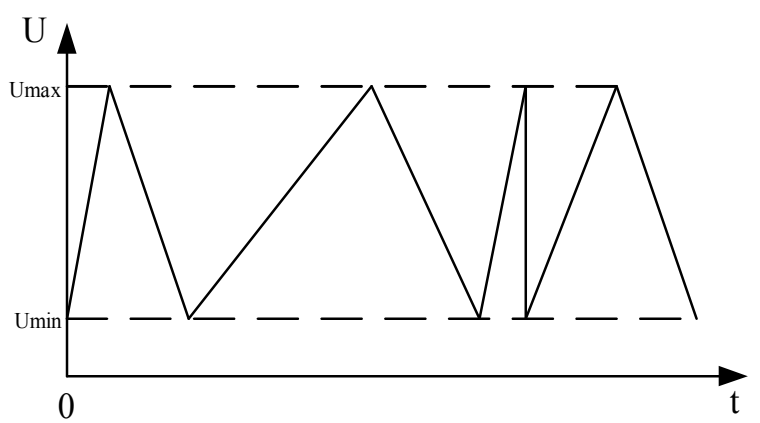

b)

Fig. 3. Nature of the supply voltage change: $a$ - regular; $b$ - irregular

The modulator in the presented construction pattern is designed to simulate a complex-modulated character of the emitted signal [9]. Connection of the power generation and control unit to a high- 
frequency generator allows to control the spectrum width and the amplitude of the output signal of the generator. In this case, the range of the change in the spectrum width and the amplitude of the signal at its output depends on the range of variation in the supply voltage of the high-frequency generator, at which the signal generation is ensured by the high-frequency generator. The periodic (regular or irregular) change in the supply voltage from the minimum to the maximum value and back is carried out according to a linear or non-linear law (Fig. 3) with the recurrence interval from several seconds to tens of minutes.
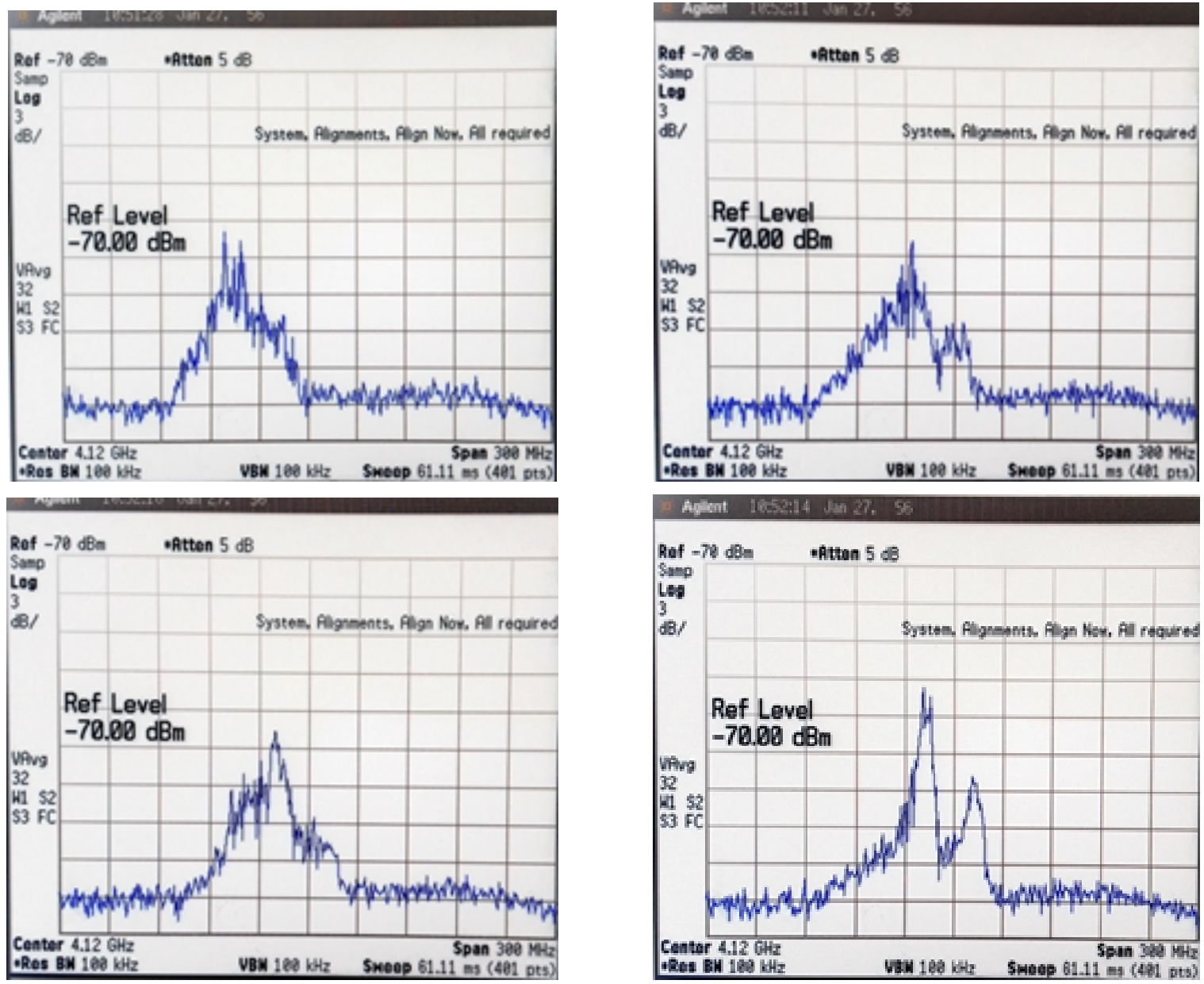

Fig. 4. Temporary varieties of the spectrum of the simulated microwave solar radiation

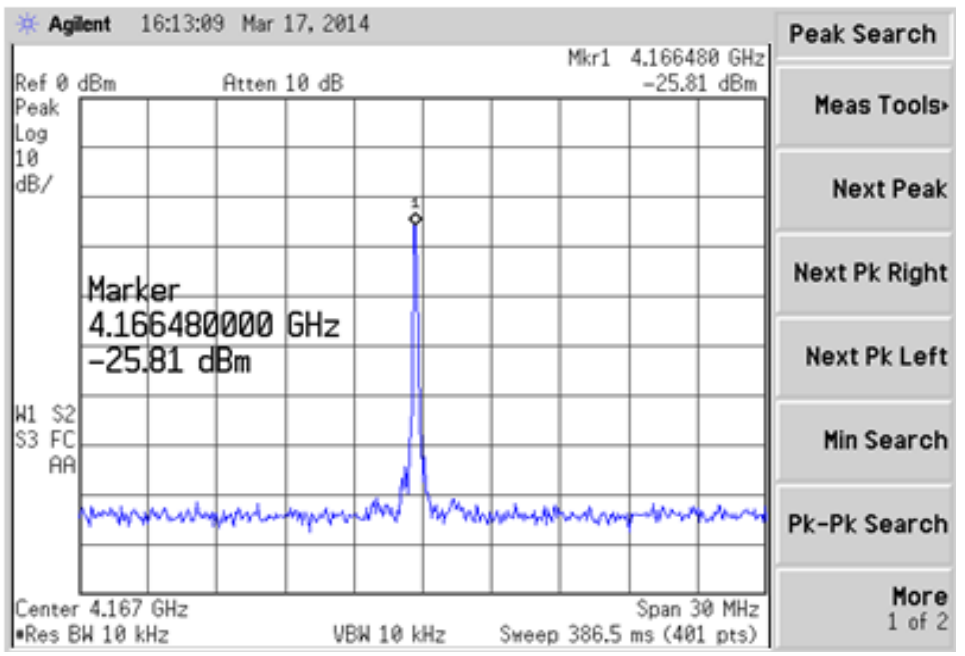

Fig. 5. Spectrum of mono-frequency electromagnetic radiation 


\section{Краткие сообщения}

Such a program mode of changing the supply voltage makes it possible to generate the necessary ripple in the specified range of time values, which are radiated by the antenna (Fig. 4). This device also provides the simulation of radiation of anthropogenic origin, which is a mono-frequency radiation at the fixed frequency of about $4 \mathrm{GHz}$ (Fig. 5).

\section{Conclusion}

Among the variety of external factors that formed various biorhythms of organisms in the evolution process, the priority role belongs to the Sun [10]. The rhythmicity of the processes in the body at various levels of its organization is the most important stabilizing and regulating factor of its internal environment. The change in this rhythm is directly related to the disturbance of the body's homeostasis. The study of external natural and technogenic microwave radiation effect on organisms and on their biorhythms is one of the promising directions for developing effective methods for the prevention and treatment of a wide range of human diseases. Restoration of one or another biorhythm reflects the main goal of disturbed homeostasis correction. Among the large number of already studied biorhythms, characteristic for organisms, high frequency rhythms are of the greatest interest. Synchronization with other various midfrequency and low-frequency rhythms of organisms is associated with them [11].

The constructed device for simulating solar electromagnetic radiation microwave bursts has no analogues in the world. It allows us to obtain new knowledge about the interaction of organisms with electromagnetic radiation of natural and technogenic origin, their influence on various high-frequency biorhythms of organisms and microorganisms in particular.

\section{References}

1. Wilde G., Smerd S., Veyss A. [Sporadic Radiation of the Sun]. Advances in Physical Sciences, 1964, vol. LXXXIV, iss. 1, pp. 99-168. (in Russ.)

2. Darovskykh S., Shishkova Y., Popechitelev E., Vdovina N. Mikrovolnovaya geliobiologija: monografija ['Microwave Heliobiology: Monography]. Chelyabinsk, South Ural St. Univ. Publ., 2016, $99 \mathrm{p}$.

3. Grigor'ev Y. Elektromagnitnye polya i zdorov'e cheloveka [Electromagnetic Fields and Human Health]. Moscow, RUDN Publ., 2002. 177 p.

4. Darovskykh S., Shishkova Y., Vdovina N., Shishkova E. [Comparative Evaluation of the Modifying Effect of Microwave Radiation of Natural and Anthropogenic Origin on Staphylococcus Aureus]. Biomedical Radio Electronics, 2015, no. 3, pp. 50-55. (in Russ.)

5. Chizhevskiy A.L. Zemnoe ekho solnechnykh bur' [Earthly Echo of Solar Storms]. Moscow, Thought Publ., 1973. 347 p.

6. Zheleznyakov V.V. Radioizluchenie Solntsa i Planet [Radio Emission from the Sun and Planets]. Moscow, Science Publ., 1964. 560 p.

7. Biderman V. Teoriya mekhanicheskikh kolebaniy [Theory of Mechanical Oscillations]. Moscow, High Scholl Publ., 1980. p. 408.

8. Vdovina N.V. Apparatno-programmnye sredstva snizhenija rezistentnyh svojstv uslovnopatogennyh mikroorganizmov [Hardware and Software to Reduce the Resistant Properties of Conditionally Pathogenic Microorganisms]. Thesis for the degree of candidate of technical sciences. Saint Petersburg Electrotechnical University LETI. St. Petersburg, 2016. 162 p.

9. Darovskykh S., Shishkova Y., Vdovina N., Vodyanitsky E. [The Principles of Constructing Devices for Restoring the Controlling Role for the Organisms of the Microwave Radiation of the Sun (a Brief Review of the Results of Research in the Field of Microwave Heliobiology)]. Biomedical radio electronics, 2017, no. 6, pp. 61-67. (in Russ.)

10. Presman A. Elektromagnitnaya signalizatsiya v zhivoy prirode. Fakty, gipotezy, puti issledovaniya [Electromagnetic Signaling in Living Nature. Facts, Hypotheses, Ways of Research]. Moscow, Sov. Radio Publ., 1974. 64 p.

11. Chibisov S.M. Bioritmy i kosmos: monitoring kosmobiosfernykh svyazey [Biorhythms and Cosmos: Monitoring of Cosmobiospheric Links]. Moscow, Monograph Publ., 2013. 442 p.

Received 25 August 2017 


\title{
УСТРОЙСТВО МОДЕЛИРОВАНИЯ МИКРОВОЛНОВЫХ ВСПЛЕСКОВ ЭЛЕКТРОМАГНИТНОГО ИЗЛУЧЕНИЯ СОЛНЦА
}

\author{
С.Н. Даровских ${ }^{1}$, Ю.С. Шишкова ${ }^{2}$, Н.В. Вдовина ${ }^{1}$, Н.Н. Гудаев ${ }^{1}$, В.Н. Багаев ${ }^{1}$, \\ А.Р. Комогорова ${ }^{1}$, Д.В. Кочкина ${ }^{1}$, О.Д.А. Абдалгабар ${ }^{1}$ \\ ${ }^{1}$ Южно-Уральский государственный университет, г. Челябинск, Россия, \\ ${ }^{2}$ Южно-Уральский медицинский университет, г. Челябинск, Россия
}

\begin{abstract}
Обоснована актуальность проведения исследований по оценке модифицирующей роли всплесков микроволнового излучения Солнца на биоритмы организмов. Отмечено, что необходимое условие проведения таких исследований связано с разработкой устройства их моделирования. Приведены основные соотношения, определяющие физические основы построения такого устройства, а также функциональные его возможности. Разработанное устройство моделирования микроволновых всплесков электромагнитного излучения Солнца в диапазоне частот около 4ГГц не имеет аналогов в мире. Оно позволяет получить новые знания о взаимодействии организмов с электромагнитными излучениями природного и техногенного происхождения, их влиянии на различные высокочастотные биоритмы организмов и микроорганизмов в частности.
\end{abstract}

Ключевые слова: микроволновые всплески, биоритмы, микроволновое излучение.

\section{Литература}

1. Уайлд, Дж. Спорадическое излучение Солниа / Дж. Уайлд, С. Смерд, А. Вейсс // Успехи физических наук. - 1964. - T. LXXXIV, вып. 1. - C. 99-168.

2. Микроволновая гелиобиология: моногр. / С.Н. Даровских, Ю.С. Шишкова, Е.П. Попечителев, Н.В. Вдовина; под ред. С.Н. Даровских. - Челябинск: Издат. иентр ЮУрГУ, 2016. $99 \mathrm{c.}$

3. Григорьев, Ю.Г. Электромагнитные поля и здоровье человека / Ю.Г. Григорьев. - М.: РУДН, 2002. - 177 c.

4. Сравнительная оченка модифичирующего действия микроволновых излучений природного и антропогенного происхождения на золотистый стафилококк / С.Н. Даровских, Ю.С. Шиикова, Н.В. Вдовина, Е.В. Шиикова // Биомед. радиоэлектроника. - 2015. - № 3. - С. 50-55.

5. Чижевский, А.Л. Земное эхо солнечных бурь / А.Л. Чижевский. - М.: Мысль, 1973. - 347 с.

6. Железняков, В.В. Радиоизлучение Солнияа и планет / В.В. Железняков. - М.: Наука, 1964. $560 \mathrm{c.}$

7. Бидерман, В.Л. Теория механических колебаний / В.Л. Бидерман. - М.: Высш. ик., 1980. $408 \mathrm{c}$.

8. Вдовина, Н.В. Аппаратно-программные средства снижения резистентных свойств условнопатогенных микроорганизмов: дис. ... канд. техн. наук / Н.В. Вдовина. - СПб.: Санкт-Петербургский государственный электротехнический университет «ЛЭТИ» им. В.И. Ульянова (Ленина), 2016. $-162 \mathrm{c}$.

9. Даровских, С.Н. Принџипы построения устройств восстановления управляющей роли для организмов микроволнового излучения Солнща (краткий обзор результатов исследования в области микроволновой гелиобиологии) / Ю.С. Шишкова, Н.В. Вдовина, Е.В. Водяниикий // Биомед. радиоэлектроника. - 2017. - № 6. - С. 61-67.

10. Пресман, А.С. Электромагнитная сигнализащия в живой природе. Факты, гипотезы, пути исследования / А.С. Пресман. - М.: Сов. радио, 1974. - 64 с.

11. Чибисов, С.М. Биоритмы и космос: мониторинг космобиосферных связей / С.М. Чибисов, Г.С. Катинас, М.В. Рагульская. - М.: Монография. - 2013. - 442 с. 
Даровских Станислав Никифорович, д-р техн. наук, заведующий кафедрой инфокоммуникационных технологий, Южно-Уральский государственный университет, г. Челябинск; darovskih.s@mail.ru.

Шишкова Юлия Сергеевна, д-р мед. наук, профессор кафедры микробиологии, вирусологии, иммунологии и клинической лабораторной диагностики, Южно-Уральский медицинский университет, г. Челябинск; shishkova_yulia@mail.ru.

Вдовина Надежда Владимировна, канд. техн. наук, доцент кафедры инфокоммуникационных технологий, Южно-Уральский государственный университет, г. Челябинск; nadzh@yandex.ru.

Гудаев Николай Николаевич, инженер кафедры инфокоммуникационных технологий, Южно-Уральский государственный университет, г. Челябинск; gudaevnn@susu.ac.ru.

Багаев Владимир Николаевич, канд. техн. наук, доцент кафедры инфокоммуникационных технологий, Южно-Уральский государственный университет, г. Челябинск; bagaevvn@susu.ac.ru.

Комогорова Алиса Робертовна, аспирант кафедры инфокоммуникационных технологий, Южно-Уральский государственный университет, г. Челябинск; komogorovaar@susu.ru.

Кочкина Дарья Викторовна, старший преподаватель Института лингвистики и международных коммуникаций, Южно-Уральский государственный университет, г. Челябинск; englmnk@gmail.com.

Абдалгабар Омер Джамал Абдалгабар, аспирант кафедры инфокоммуникационных технологий, Южно-Уральский государственный университет, г. Челябинск.

Поступила в редакцию 25 августа 2017 г.

\section{ОБРАЗЕЦ ЦИТИРОВАНИЯ}

A Device for Simulating Solar Electromagnetic Radiation Microwave Bursts / S.N. Darovskikh, Yu.S. Shishkova, N.V. Vdovina et al. // Вестник ЮУрГУ. Серия «Компьютерные технологии, управление, радиоэлектроника». - 2017. - Т. 17, № 4. - С. 154-160. DOI: $10.14529 /$ ctcr170417

\section{FOR CITATION}

Darovskikh S.N., Shishkova Yu.S., Vdovina N.V., Gudaev N.N., Bagaev V.N., Komogorova A.R., Kochkina D.V., Abdalgabar O.J.A. A Device for Simulating Solar Electromagnetic Radiation Microwave Bursts. Bulletin of the South Ural State University. Ser. Computer Technologies, Automatic Control, Radio Electronics, 2017, vol. 17, no. 4, pp. 154-160. DOI: $10.14529 /$ ctcr170417 